\title{
Untreated Childhood Subependymal Giant Cell Astrocytoma
}

National Cancer Institute

\section{Source}

National Cancer Institute. Untreated Childhood Subependymal Giant Cell Astrocytoma.

NCl Thesaurus. Code C115955.

A finding of subependymal giant cell astrocytoma in childhood that has not been treated. 